\title{
Experimental evidence for the possible exposure of workers to hexachlorobenzene by skin contamination
}

\author{
Akio Koizumi
}

\begin{abstract}
The absorption of dermally applied ${ }^{14} \mathrm{C}$ hexachlorobenzene $\left({ }^{14} \mathrm{C}-\mathrm{HCB}\right.$; ranging from 2.5 to $2.6 \mathrm{mg} / 4 \mathrm{~cm}^{2}$ ) was investigated in the rat. The absorbed portion increased from $1 \%$ at six hours to $9 \cdot 7 \%$ at 72 hours after dosing and blood concentrations of ${ }^{14} \mathrm{C}$ increased linearly with time. The rate of absorption was 3.51 (SD $0.81) \mu \mathrm{g} / \mathrm{h} / 4 \mathrm{~cm}^{2}$ and the absorption constant 1.40 (SD 0.33 ) $\times 10^{-3} / \mathrm{h}$. Washing with soap at six hours after dosing removed $34 \%$ of the dose and decreased absorption by $50 \%$ in the next 66 hours. Finally, the compartment model, which incorporated the absorption constant, simulated the time profile of HCB kinetics in blood, and that of cumulative excretion in rats. The model with the absorption constant for the rat was then scaled up for a $70 \mathrm{~kg}$ worker, whose exposure was assumed to be exclusively dermal. A rough dermal contamination, which corresponds to the tentative HCB critical blood concentration of $200 \mathrm{ppb}$, was calculated for different simulated biological half lives. It was $18.2 \mathrm{mg}$ for $100,5.02 \mathrm{mg}$ for 365 , and $2.56 \mathrm{mg}$ for 730 day half lives. The study indicates that dermal contamination can be a source of HCB body burden, and that personal hygiene, such as taking $a$ shower and hand washing is likely to have a profound influence on the body burden of HCB.
\end{abstract}

Hexachlorobenzene (HCB), a fungicidal compound and a byproduct in the manufacture of chlorinated solvents, is a suspected carcinogen in man. ${ }^{1}$ Thus exposure to this compound, known to occur among workers manufacturing chlorinated solvents presents a health hazard. ${ }^{23}$ Intensive investigation into HCB exposure showed that concentrations of $\mathrm{HCB}$ in blood were strongly associated with years of employment, but poorly correlated with either traditional industrial hygiene measures or job

Department of Hygiene, Akita University School of Medicine, Akita 010, Japan

A Koizumi category based exposure estimates. ${ }^{2}$ Thus blood concentrations of HCB in employees appeared to be influenced more by plant housekeeping procedures, personal hygiene, or habits, than by atmospheric concentrations. Consequently, it has been assumed that body burdens of HCB derive mostly from dermal contamination and are dependent on personal hygiene, such as hand washing, bathing, or taking showers.

The aim of our study was to investigate whether dermal exposure to HCB can reasonably explain blood HCB concentrations found in plant workers. Firstly, the kinetics of HCB in rats after dermal application of HCB was investigated. Secondly, the effect of washing on body burden was evaluated. Finally, a pharmacokinetic model, originally developed for monkeys, ${ }^{4}$ was applied to man and the relation between intensity of exposure and blood concentration was studied. The simulation results indicate that small doses $(18.2$ to $2.56 \mathrm{mg}$ ) applied to the skin maintained a high blood concentration of HCB (200 ppb).

\section{Materials and methods \\ ANIMALS}

Male Fisher 344 rats, purchased from the Charles River Breeding Laboratory (Kingston, NY, USA) and weighing 230 (SD 6) g, were used. On arrival at the laboratory, the health state of the animals was checked by the laboratory veterinarian, and the rats were kept in the laboratory for one week to acclimatise. They were housed in a room with controlled temperature $\left(23^{\circ} \mathrm{C}\right)$, relative humidity $(50 \%)$, and photocycle (12 hours) with roughly 10 air changes each hour. Individual rats were identified by metal ear tags. Food (certified rodent chow No 5002, Ralston Purina Company, St Louis, MO) and municipal water were supplied to animals ad libitum.

\section{TEST CHEMICALS}

Uniformly labelled ${ }^{14} \mathrm{C}-\mathrm{HCB}$, with a specific activity of $15.3 \mathrm{mCi} / \mathrm{mmol}$ and with a radiochemical purity quoted as greater than $98 \%$, was purchased from Pathfinder Lab Inc, St Louis, MO. The radiochemical purity determined by radioliquid chromatography was found to be $100 \%$.

Non-radiolabelled HCB purchased from Alfa 
Products (Denvers, MA), was more than $99 \%$ pure as determined by direct mass spectrometry.

\section{DOSING SOLUTION}

A dosing solution containing approximately $25.0 \mathrm{mg}$ ${ }^{14} \mathrm{C}-\mathrm{HCB} / \mathrm{ml}$ tetrachloroethylene was prepared by dissolving known amounts of ${ }^{14} \mathrm{C}-\mathrm{HCB}$ and $\mathrm{HCB}$ in tetrachloroethylene. The specific activity of the final dosing solution was $6176 \mathrm{dpm} / \mu \mathrm{g}$ HCB.

\section{EXPERIMENT 1}

Dermal absorption rate was determined after the application of ${ }^{14} \mathrm{C}-\mathrm{HCB}$ dosing solution to the skin. Hair from the back area of about 8 to $10 \mathrm{~cm}^{2}$ was shaved with electric clippers under methoxyflurane anaesthesia. The dosing solution (approximately $100 \mu \mathrm{l}$ of ${ }^{14} \mathrm{C}-\mathrm{HCB}$ ) was applied to a $2 \mathrm{~cm} \times 2 \mathrm{~cm}$ marked area. The amount of dosing solution was determined by weighing a glass gas tight syringe before and after delivery. The actual dose was calculated on the basis of the body weight of the individual animals. After application, the vehicle (tetrachloroethylene) was prompted to evaporate by a heat lamp. Immediately after evaporation, the dosed area was covered with a piece of teflon film $(3 \mathrm{~cm} \times 3 \mathrm{~cm} \times 0.125 \mathrm{~mm})$ and fixed in place with waterproof adhesive tape and protecting jacket (Alice King Catham, Los Angeles, CA). Animals were transferred to either wire mesh cages or Roth type metabolic cages until they were killed. Animals in the wire mesh cages were killed at 12 and 48 hours after dosing, and those in Roth type metabolic cages were killed at six, 24, and 72 hours after dosing. In the last group, a mass balance study was conducted.

\section{EXPERIMENT 2}

In this series of studies, the effect of washing the skin on body burden of HCB was investigated. After the application of a single dose the area was protected as described above. Animals were then transferred to Roth type metabolic cages. At six hours after dosing, rats were anaesthetised with methoxyflurane and the contaminated area was wiped 20 times with cotton swabs soaked in $0.5 \%(\mathrm{w} / \mathrm{w})$ soap in water (Ivory Liquid, Proctor and Gamble, Cincinnati, $\mathrm{OH}$ ) and were covered again with a new teflon film, which was fixed with waterproof adhesive tape and a new protecting jacket. The old jacket, teflon patches, adhesive tapes, and cotton swabs were collected for analysis of radioactivity. Rats were killed 72 hours after dosing ( 66 hours after washing).

\section{TISSUE AND SAMPLE COLLECTIONS}

Rats were anaesthetised with methoxyflurane and exanguinated via a cardiac puncture. Blood was collected in heparinised tubes, sealed, and stored at $-20^{\circ} \mathrm{C}$. Livers were also collected. Skin at the site of dosing was washed with tetrachloroethylene soaked cotton swabs. The whole carcass was skinned after the dosing and another area $(3 \mathrm{~cm} \times 3 \mathrm{~cm})$ remote from the dosed site on the lumbar region was removed. The subcutaneous tissues were separated and stored frozen until analysis. Also, 24 hour urine and faeces samples were collected separately from animals put in Roth type metabolic cages, and these were stored at $-20^{\circ} \mathrm{C}$ until analysis.

\section{RADIOACTIVITY DETERMINATION}

Cotton swabs, which were used to wipe dosed areas, were counted by liquid scintillation spectrometry in vials containing aqueous counting scintillant (ACS, Amersham Inc, Buckinghamshire, UK). Teflon films were soaked and washed in a known volume of tetrachloroethylene, and jackets in toluene. Aliquots of tetrachloroethylene and toluene were counted by liquid scintillation spectrometry.

Radioactivity in the urine was determined by scintillation counting of aliquots of urine mixed with ACS. Skin samples were ground in liquid nitrogen, mixed with water and ACS, and counted by liquid scintillation spectrometry.

Aliquots of blood, aqueous homogenates of carcass, faeces, and liver were combusted with a biological material oxidiser (Harvey Instrument Corp, Hillsdale, NJ). The ${ }^{14} \mathrm{CO}_{2}$ was trapped and then quantified by liquid scintillation spectrometry.

Subcutaneous tissues were solubilised by a tissue solubiliser (Amersham Inc, Buckinghamshire, UK), mixed with ACS, and quantified by liquid scintillation spectrometry.

\section{COMPUTER SIMULATION}

Simulation of differential equations (appendix) describing the kinetics of HCB were formulated in a computer program as outlined by Yang et al (fig 1). ${ }^{4}$

\section{Dose}

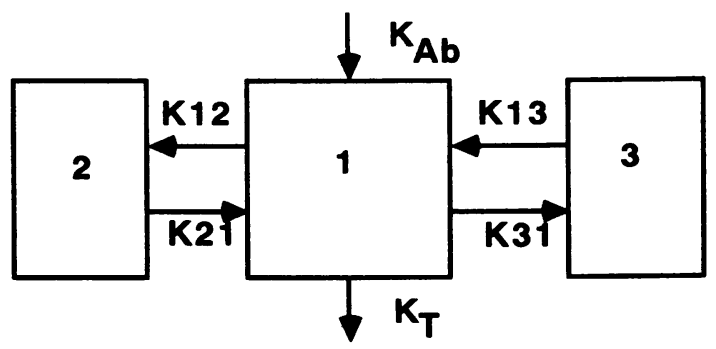

Figure 1 Pharmacokinetic model used to simulate the human dose by dermal route. Compartment 1 is the central compartment containing blood and any tissues for which the distribution phases are very rapid. The dermally absorbed $H C B$ directly enters this compartment. Compartment 2 and 3 are, respectively, a slow and a fast tissue compartment. Exchange between the central and peripheral compartments is controlled by the rate constants $K 12, K 21, K 13$, and $K 31$. Excretion and metabolism are controlled by $K_{T}$. For values actually used refer to table 4. 
Table 1 Disposition of ${ }^{14} \mathrm{C}$-hexachlorobenzene after dermal application

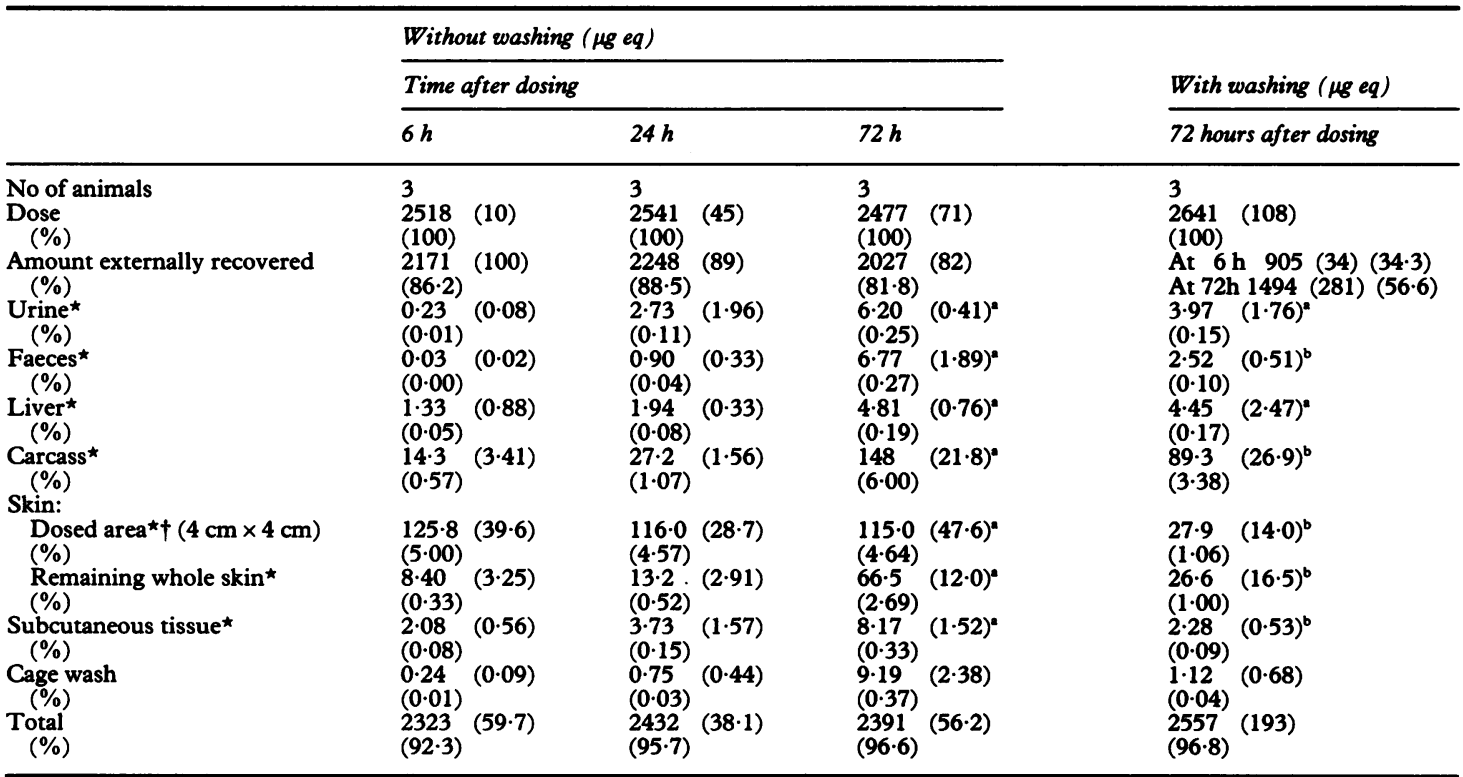

Values are mean $(\mathrm{SD}) \mu \mathrm{g}$ eq. Lower values in parentheses are the mean percentages.

*Comparisons were made among values obtained at 72 hours without washing and with washing by one way analysis of variance (ANOVA).

The same superscript letter indicates no significant difference between the two values, whereas the different letters indicate a significant difference $(\mathrm{p}<0.05)$

+ Skin $(4 \mathrm{~cm} \times 4 \mathrm{~cm})$ covered the dosed area $(2 \mathrm{~cm} \times 2 \mathrm{~cm})$.

Simulations were conducted with a basic program and run on a Macintosh computer.

\section{STATISTICAL ANALYSIS}

Comparisons of means were performed by one way analysis of variance. ${ }^{5} \mathrm{~A} p$ value $<0.05$ was considered statistically significant.

\section{Results}

MASS BALANCE AND DISPOSITION

In the present study, mean recoveries ranged from 92.3 to $96.8 \%$ (table 1 ). A large proportion of the applied doses, ranging from 81.8 to $88.5 \%$, was externally recovered from teflon films, jackets, and swabs. Amounts recovered from the dosed skin areas were a fairly constant $5 \%$ of the applied dose when areas were not washed. Thus a large proportion of the dose remained unabsorbed.

In the carcass an average $0.57 \%$ of the dose was recovered at six hours and $6.00 \%$ at 72 hours. The second largest proportion was from the skin fraction, accounting for $0.33 \%$ at six hours and $2.69 \%$ at 72 hours. Very much less was recovered from urine, faeces, and liver.

By washing at six hours after dosing, $34 \%$ of the ${ }^{14} \mathrm{C}-\mathrm{HCB}$ was removed from the dosed skin area. In accordance with the decrease in dose, significant reductions in ${ }^{14} \mathrm{C}-\mathrm{HCB}$ were found at 72 hours in the carcass $(44 \%$ reduction, $p<0.05)$, in the skin of the dosed area $(77 \%$ reduction, $p<0.05)$, in the remaining skin $(63 \%$ reduction, $\mathrm{p}<0.05)$, and in urine (40\% reduction) and faeces $(63 \%$ reduction, $p$ $<0.05)$, suggesting that washing can decrease to a significant degree the amounts of ${ }^{14} \mathrm{C}-\mathrm{HCB}$ absorbed from the skin.

\section{TIME COURSE PROFILES}

Concentrations of ${ }^{14} \mathrm{C}-\mathrm{HCB}$ in liver and blood increased steadily after dermal application. The cumulative excretion in urine and faeces (table 1) showed similar time profiles to those of blood (fig 2). Washing decreased mean ${ }^{14} \mathrm{C}-\mathrm{HCB}$ concentrations in blood from 0.263 (SD 0.052) to 0.128 (SD 0.056) $\mu \mathrm{g}$ eq of $\mathrm{HCB} / \mathrm{g}$ (p < 0.05; fig 2), and in liver from 0.680 (SD 0.159) to 0.556 (SD 0.271) $\mu \mathrm{g}$ eq of $\mathrm{HCB} / \mathrm{g}$ liver at 72 hours.

CUMULATIVE ABSORPTION OF HCB AFTER DERMAL CONTAMINATION AND ITS ABSORPTION CONSTANT Both time profile data and mass balance indicated the systemic distribution of ${ }^{14} \mathrm{C}-\mathrm{HCB}$ in the whole body after dermal exposure. The cumulative absorbed budy burden, which is the sum of ${ }^{14} \mathrm{C}-\mathrm{HCB}$ 


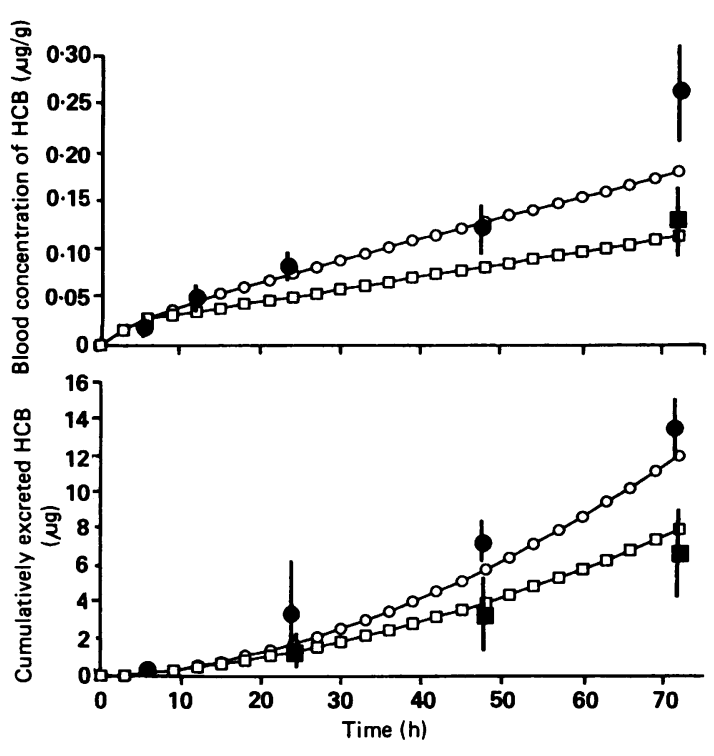

Figure 2 Simulated blood concentrations and cumulative excreted amounts in rats using a pharmacokinetic model. Open circles and squares indicate the computer simulated values without washing and with washing respectively. The dots and solid squares indicate the observed values without washing and with washing, respectively.

recovered from urine, faeces, liver and carcass, from the skin not directly contaminated, and the subcutaneous tissue increased with the duration of exposure after dosing, from $1.05 \%$ at six hours to $9.71 \%$ at 72 hours (table 2). As expected, the cumulative absor- bed portions were decreased by almost $50 \%$ by washing.

The absorption rate across the skin was calculated by assuming that the absorption process could be described by a one compartment linear pharmacokinetic model (see appendix) in which the cumulative absorption is a linear function of time. This assumption was justified by the linear increases found in the cumulative absorbed amounts of ${ }^{14} \mathrm{C}-\mathrm{HCB}$. The absorption constant was calculated to be 1.40 (SD $0.33) \times 10^{-3} / \mathrm{h}$ (table 3 ).

\section{RELATION BETWEEN BLOOD CONCENTRATION AND DERMAL DOSE}

It is of practical importance to determine whether dermal exposure to HCB can account for the blood HCB concentrations found in plant workers. To answer this question, a pharmacokinetic model was developed for dermal exposure. Although it is well known that physiologically based pharmacokinetic models are superior to compartment models, ${ }^{6}$ the limited information on physiological parameters did not allow us to take this approach. Consequently, quantitative analyses were performed using a three linear compartment model (fig 1). ${ }^{3}$ The model was applied to the present data to simulate HCB kinetics with or without washing (fig 2). In this model, parameters were the same as those in monkeys, except that the elimination constant $\left(\mathrm{K}_{\mathrm{T}}\right)$ was eight times larger in rats than in monkeys (table 4). The model was then scaled up for a $70 \mathrm{~kg}$ worker, assuming the direct incorporation of dermally applied HCB into compartment 1 (fig 1). It was also

Table 2 Cumulative HCB absorbed after dermal absorption with or without washing contaminated area

\begin{tabular}{|c|c|c|c|c|}
\hline Washing & $\begin{array}{l}\text { Exposure duration } \\
\text { (h) }\end{array}$ & $\begin{array}{l}\text { Total dose } \\
(\mu g \text { eq })\end{array}$ & $\begin{array}{l}\text { Cumulatively absorbed } \\
\text { amount of } H C B^{\star} \dagger \\
(\mu g \text { eq) }\end{array}$ & $\begin{array}{l}\text { Mean relativef } \\
\text { absorption } \\
(\%)\end{array}$ \\
\hline- & $\begin{array}{r}6 \\
24 \\
72 \\
72\end{array}$ & $\begin{array}{l}2518(10) \\
2541 \quad(45) \\
2477(71) \\
2641(108)\end{array}$ & $\begin{array}{c}26 \cdot 4(4 \cdot 17) \\
57 \cdot 2(1 \cdot 40) \\
240 \cdot 5(12 \cdot 2) \\
129 \cdot 1(47 \cdot 7)\end{array}$ & $\begin{array}{l}1 \cdot 05 \\
2 \cdot 67 \\
9 \cdot 71 \\
4 \cdot 90\end{array}$ \\
\hline
\end{tabular}

*Values are mean (SD). Three animals were killed for each time point.

$\dagger$ Total amounts recovered from urine, faeces, liver, carcass, and the remaining skin (except the dose area) and subcutaneous tissues. $\ddagger$ Mean relative absorption was calculated by dividing the cumulative absorbed amount by the total dose.

$\S$ The dose initially applied was $2641(108.9) \mu \mathrm{g}$ of which $904.5(34.0) \mu \mathrm{g}$ was washed at six hours.

Table 3 Estimation of absorption constants

\begin{tabular}{|c|c|c|c|c|c|}
\hline & $\begin{array}{l}\text { Exposure } \\
\text { duration } \\
\text { (h) }\end{array}$ & $\begin{array}{l}\text { Mean } \\
\text { dose } \\
\left(\mu g / 4 \mathrm{~cm}^{2}\right)\end{array}$ & $\begin{array}{l}\text { Mean cumulative } \\
\text { absorbed amount } \dagger \\
(\mu g)\end{array}$ & $\begin{array}{l}\text { Absorption } \\
\text { rate } \neq \\
\left(\mu g / \mathrm{h} / 4 \mathrm{~cm}^{2}\right)\end{array}$ & $\begin{array}{l}\text { Absorption } \\
\text { constant }\left(K_{A b}\right) \S \\
\left(\times 10^{-3} / h\right)\end{array}$ \\
\hline Mean (SD) & $\begin{array}{r}6 \\
24 \\
72 \\
-\end{array}$ & $\begin{array}{r}2518 \\
2514 \\
2478 \\
-\end{array}$ & $\begin{array}{r}26 \cdot 6 \\
67 \cdot 2 \\
240 \cdot 5 \\
-\end{array}$ & $\begin{array}{l}4 \cdot 40 \\
2 \cdot 80 \\
3 \cdot 34 \\
3 \cdot 51(0 \cdot 81)\end{array}$ & $\begin{array}{l}1 \cdot 76 \\
0 \cdot 87 \\
1 \cdot 40 \\
1.40(0.33)\end{array}$ \\
\hline
\end{tabular}

* Mean of the dose actually applied to the skin.

†Total amounts recovered from the urine, faeces, liver, carcass, skin (except the dosing area), and subcutaneous tissues.

†Defined as: Cumulative absorbed amount $\left(\mu \mathrm{g} / 4 \mathrm{~cm}^{2}\right) /$ Time period $(\mathrm{h})$.

$\S$ Defined as: Absorption rate $\left(\mu \mathrm{g} / \mathrm{cm}^{2} / \mathrm{h}\right) / \operatorname{Dose}\left(\mu \mathrm{g} / 4 \mathrm{~cm}^{2} / \mathrm{h}\right)$. 
Table 4 Parameters used in pharmacokinetic model

\begin{tabular}{|c|c|c|c|c|}
\hline Parameters & Unit & Rat & Monkey ${ }^{\star}$ & $\begin{array}{l}\text { Parameters used to } \\
\text { simulate human exposure }\end{array}$ \\
\hline $\begin{array}{l}\text { K12 } \\
\text { K21 } \\
\text { K13 } \\
\text { K31 } \\
\mathrm{K}_{\mathrm{T}} \\
\mathrm{K}_{\text {Ab }} \\
\text { Dose } \\
\mathrm{V}_{\mathrm{L}}\end{array}$ & $\begin{array}{l}(-/ \mathbf{h}) \\
(-/ \mathbf{h}) \\
(-/ \mathbf{h}) \\
(-/ \mathbf{h}) \\
(-/ \mathbf{h}) \\
(-/ \mathbf{h}) \\
(\mu \mathbf{g}) \\
(\mathbf{L} / \mathbf{k g})\end{array}$ & $\begin{array}{l}0.391 \times 10^{-3} \\
0.153 \times 10^{-5} \\
0.108 \\
0.0679 \\
2.0 \times 10^{-3} \\
2.0 \times 10^{-3} \\
2500 \\
3.5\end{array}$ & $\begin{array}{l}0.391 \times 10^{-3} \\
0.153 \times 10^{-5} \\
0.108 \\
0.0679 \\
0.27 \times 10^{-3} \\
- \\
\overline{3.5}\end{array}$ & $\begin{array}{l}\mathrm{K} 12 \dagger \\
0.153 \times 10^{-5} \\
0.108 \\
0.0679 \\
\mathrm{~K}_{\mathrm{T}}^{\dagger} \\
2.0 \times 10^{-3} \\
\frac{-}{3.5}\end{array}$ \\
\hline
\end{tabular}

$\star$ Originally obtained from reference 4.

†The total of $\mathrm{K} 12+\mathrm{K}_{\mathrm{T}}$ was changed depending on the biological half lives (see, Equation B-11 in appendix). For a biological half life of 100 days, $\mathrm{K} 12+\mathrm{K}_{\mathrm{T}}$ was $0.00749(-/ \mathrm{h})$, for that of 365 days, it was $0.0002049(-/ \mathrm{h})$, and for that of 730 days, it was $0.00010025(-/ \mathrm{h})$. For simulation, the half of the total values were assigned to $K 12$ and $K_{T}$ by assuming $K 12=K_{T}$. This assignment has little influence on the relation between blood concentrations and dermal doses under a steady state when $\mathrm{K} 21$ is much smaller than either $\mathrm{K} 12$ or $\mathrm{K}_{\mathrm{T}}$ as discussed in the appendix.

assumed that exposure was exclusively by the dermal route, and that the absorption constant in workers was the same as in rats.

The critical dermal doses resulting in $200 \mathrm{ppb}$ of HCB in blood, regarded as the upper safe limit, ${ }^{2}$ were estimated for three different biological half lives by the Equation B-14 (appendix). Using these initial values, computer simulations for half lives of 100 days, 365 days, and 730 days were performed to calculate the doses that gave HCB concentrations in blood close to $200 \mathrm{ppb}$ (table 5).

\section{Discussion}

In the present study, absorption of HCB was found to proceed as a linear function of time after dermal application. The time cumulative absorbed amount profile enabled the calculation of the absorption rate constant for rats. The pharmacokinetic model, incorporating dermal absorption, gave estimates of dermal doses resulting in $200 \mathrm{ppb}$ HCB in blood after long term (year order) exposures. Such a blood concentration can be the result of dermal exposure ranging from $18.2 \mathrm{mg}$ to $2.56 \mathrm{mg}$. Such a contamination is small enough to go unnoticed. The calculated doses have inevitable errors as they were given by a simple three compartment model in which parameters obtained from rats and monkeys were used. The model, therefore, ignored species differences and differences in skin permeability at various anatomical sites, both of which are known to be important factors. ${ }^{78}$ Despite these simplifications and uncertainties inherent in the model, the present study demonstrates the significance of dermal absorption.

It has been reported that blood concentrations of HCB in employees correlated poorly with either traditional hygiene measures or job category based exposure estimates. ${ }^{2}$ Trace amounts of HCB may be easily absorbed from skin if workers do not wash contaminated skin areas intentionally. Therefore, persistent skin contamination may be more important than airborne HCB. In such cases, the dermal

Table 5 Calculated dermal dose level with equation (B-14) corresponding to blood concentration of $0 \cdot 200(\mu \mathrm{g} / \mathrm{ml})$ and computer simulated blood concentrations (in a $70 \mathrm{~kg}$ worker)

\begin{tabular}{|c|c|c|c|}
\hline \multirow[b]{5}{*}{ Simulation period (days) } & \multicolumn{3}{|c|}{ Blood concentration by computer simulation $(\mu \mathrm{g} / \mathrm{ml})$} \\
\hline & \multicolumn{3}{|c|}{ Biological half life $e^{\star}$} \\
\hline & 100 days & 365 days & 730 days \\
\hline & \multicolumn{3}{|c|}{ Dermal dose $(\mathrm{mg} / 70 \mathrm{~kg} \text { worker })^{\star}$} \\
\hline & $18 \cdot 2$ & 5.02 & $2 \cdot 56$ \\
\hline $\begin{array}{r}200 \\
400 \\
600 \\
800 \\
1000 \\
1200 \\
1600\end{array}$ & $\begin{array}{l}0 \cdot 163 \\
0.194 \\
0 \cdot 201 \\
0.203 \\
0.203 \\
0.204 \\
0.206\end{array}$ & $\begin{array}{l}0.073 \\
0 \cdot 120 \\
0 \cdot 149 \\
0 \cdot 168 \\
0 \cdot 185 \\
0 \cdot 194 \\
0 \cdot 198\end{array}$ & $\begin{array}{l}0.041 \\
0.074 \\
0 \cdot 100 \\
0 \cdot 121 \\
0 \cdot 138 \\
0 \cdot 151 \\
0 \cdot 171\end{array}$ \\
\hline
\end{tabular}

*Dermal doses corresponding to the blood concentration of $0.200 \mu \mathrm{g} / \mathrm{ml}$ were calculated using equation (B-14). For simulation, the half of the total values $\left(\mathrm{K} 12+\mathrm{K}_{\mathrm{T}}\right.$ ) were assigned to $\mathrm{K} 12$ and $\mathrm{K}_{\mathrm{T}}$ by assuming $\mathrm{K} 12=\mathrm{K}_{\mathrm{T}}$. This assignment had little influence on simulation results. The computer simulation was run using parameters listed in table 4. 
route should be taken into account, and could be monitored by biological measures as suggested by Lunde and Bjorseth ${ }^{3}$ for monitoring exposure to HCB.

Another result of the present study is the demonstration of the importance of hygiene. Washing contaminated skin with soap decreased the absorbed amount significantly (table 2). Showering and changing clothes before eating and after work are also expected to decrease skin contamination. These practices, therefore, may be effective preventive measures for all workers potentially exposed to $\mathrm{HCB}$.

I am grateful to Drs J $M$ Waechter Jr, A M Shumann, R J Nolan, and P G Watanabe (Dow Chemical USA, Michigan) for their comments on this project. I express deep thanks to Dr R H Reizt and Mrs C Reitz for their encouragement. I am also grateful to $\mathrm{Mr} M$ D Dryzga for his technical assistance.

Requests for reprints to: Akio Koizumi $\mathrm{MD}, \mathrm{PhD}$, Associate Professor, Department of Hygiene, Akita University School of Medicine, Akita 010, Japan.

\section{Appendix}

ABSORPTION KINETICS FROM THE SKIN

The absorption kinetics can be formulated as:

$$
\begin{aligned}
& \mathrm{d}[\mathrm{D}-\mathrm{HCB}] / \mathrm{dt}=-[\mathrm{D}-\mathrm{HCB}] \times \mathrm{K}_{\mathrm{Ab}} \\
& \mathrm{d}[\mathrm{Cum}-\mathrm{HCB}] / \mathrm{dt}=[\mathrm{D}-\mathrm{HCB}] \times \mathrm{K}_{\mathrm{Ab}}
\end{aligned}
$$

where [D-HCB], [Cum-HCB], and $\mathrm{K}_{A b}$ represent the dosed amount of HCB, the cumulative absorbed amount of HCB, and absorption constant, respectively.

The solutions are given as

$$
[D-H C B](t)=D_{0} \operatorname{Exp}\left(-K_{A b} \times t\right)
$$

$[C u m-H C B](t)=D_{0}\left(1-\operatorname{Exp}\left(-K_{A b} \times t\right)\right)(A-4)$

$\mathrm{D}_{0}=$ Initial dose.

When the absorption amount is small, relative to the amount of the initial dose, equations (3) and (4) are approximated by:

$$
\begin{aligned}
& {[D-H C B](t)=D_{0}\left(1-K_{A b} \times t\right)} \\
& {[C u m-H C B]=D_{0} K_{A b} \times t}
\end{aligned}
$$

In this case, therefore, the cumulative absorbed amounts become a linear function of time.
RELATION BETWEEN THE BIOLOGICAL HALF LIFE OF HCB IN THE SLOWLY ELIMINATED PHASE AND PARAMETERS OF THE PHARMACORINETIC MODEL The HCB kinetics that follow a three compartment model (fig 1) can be formalised by the set of differential equations:

$$
\begin{aligned}
& \mathrm{dHCB} 1 / \mathrm{dt}=\{\mathrm{K} 21 \times \mathrm{HCB} 2+\mathrm{K} 31 \times \mathrm{HCB} 3 \\
& +\mathrm{K}_{\mathrm{Ab}} \times \text { Dose }-\left(\mathrm{K} 12+\mathrm{K} 13+\mathrm{K}_{\mathrm{T}}\right) \times \mathrm{HCB1} \\
& \times \mathrm{VL}\} / \mathrm{VL} \\
& \mathrm{dHCB} 2 / \mathrm{dt}=\mathrm{K} 12 \times \mathrm{HCB} 1 \times \mathrm{VL}-\mathrm{K} 21 \\
& \times \text { HCB2 } \\
& \mathrm{DHCB} 3 / \mathrm{dt}=\mathrm{K} 13 \times \mathrm{HCB} 1 \times \mathrm{VL}-\mathrm{K} 31 \\
& \times \text { HCB3 } \\
& \mathrm{dHCB}_{\mathrm{T}} / \mathrm{dt}=\mathrm{K}_{\mathrm{T}} \times \mathrm{HCB} 1 \times \mathrm{VL}
\end{aligned}
$$

A biological half life has its own reality in one compartment models. Biological half lives, however, are often used for practical industrial hygiene purposes to predict the fate of chemicals in workers as these values are easily obtained by graphical analysis of blood concentration time curves. The biological half life of HCB is reported to be about two years in plant workers. ${ }^{2}$ It therefore appears meaningful to discuss how the rate constants and other parameters in other than one compartment models can be correlated with the biological half life.

If at an arbitrary time $(t=0)$ the dose becomes zero, the blood concentration $(\mathrm{HCB} 1(\mathrm{t}))$ decreases in the following manner after this moment:

$$
\begin{aligned}
& \mathrm{HCB} 1(\mathrm{t})=\mathrm{C} 1 \times \operatorname{Exp}\left(\mathrm{w}_{1} \times \mathrm{t}\right)+\mathrm{C} 2 \\
& \quad \times \operatorname{Exp}\left(\mathrm{w}_{2} \times \mathrm{t}\right)+\mathrm{C} 3 \times \operatorname{Exp}\left(w_{3} \times t\right)
\end{aligned}
$$

where, $\mathrm{C} 1, \mathrm{C} 2$, and $\mathrm{C} 3$ are the appropriate constants and $w_{1}, w_{2}$, and $w_{3}$ are the eigenvalues of the determinant B-5 (see bottom of page).

When $\mathrm{K} 21$ is much smaller than other parameters, as in the present case, the eigenvalues of the determinant (Equation B-5) can be approximated as B-6 (see bottom of page).

Because $\mathrm{K} 13$ and $\mathrm{K} 31$ are much larger than $\mathrm{K} 12$ and $K_{T}$, the eigenvalues can be approximated by equations:

$$
\begin{aligned}
& \mathrm{w}_{1}=-(\mathrm{K} 13+\mathrm{K} 31) \\
& \mathrm{w}_{2}=-\mathrm{K} 31 \times\left(\mathrm{K} 12+\mathrm{K}_{\mathrm{T}}\right) /(\mathrm{K} 13+\mathrm{K} 31) \\
& \mathrm{w}_{3}=-\mathrm{K} 21
\end{aligned}
$$

Taking into account the orders of these

$$
\begin{aligned}
& \left|\begin{array}{ccl}
-\left(\mathrm{w}+\mathrm{K} 12+\mathrm{K} 13+\mathrm{K}_{\mathrm{T}}\right) & \mathrm{K} 21 / \mathrm{VL} & \mathrm{K} 31 / \mathrm{VL} \\
\mathrm{K} 12 \times \mathrm{VL} & -(\mathrm{w}+\mathrm{K} 21) & 0 \\
\mathrm{~K} 13 \times \mathrm{VL} & 0 & -(\mathrm{w}+\mathrm{K} 31)
\end{array}\right|=0 \\
& (\mathrm{w}+\mathrm{K} 21)\left|\begin{array}{cc}
\mathbf{w}+\mathrm{K} 12+\mathrm{K} 13+\mathrm{K}_{\mathrm{T}} & \mathrm{K} 13 / \mathrm{VL} \\
\mathrm{K} 13 \times \mathrm{VL} & \mathrm{w}+\mathrm{K} 31
\end{array}\right|=0 \\
& (\mathrm{w}+\mathrm{K} 21)\left\{\mathbf{w}^{2}+\left(\mathrm{K} 12+\mathrm{K} 13+\mathrm{K}_{\mathrm{T}}+\mathrm{K} 31\right) \times \mathbf{w}+\left(\mathrm{K} 12+\mathrm{K}_{\mathrm{T}}\right) \times \mathrm{K} 31\right\}=0
\end{aligned}
$$


parameters (that is, $10^{-1}$ to $10^{-2} / \mathrm{h}$ for $\mathrm{K} 13$ and $\mathrm{K} 31$, $10^{-4} / \mathrm{h}$ for $\mathrm{K} 12$ and $\mathrm{K}_{\mathrm{T}}$, and $10^{-6} / \mathrm{h}$ for $\mathrm{K} 21$ ), the eigenvalue that actually has the most profound impact on the kinetics at the order of the year $\left(10^{4} / \mathrm{h}\right)$ is $\mathrm{w}_{2}$; that is:

$$
\mathrm{HCB} 1(\mathrm{t}) \approx \mathrm{C} 2 \times \operatorname{Exp}\left(\mathrm{w}_{2} \times \mathrm{t}\right)
$$

The half life at this phase is given approximately as:

$$
T_{1 / 2} \approx-\operatorname{In} 2 / \mathrm{w}_{2}
$$

Therefore, we finally get an equation which correlates the biological half life and the rate constants:

$$
\begin{aligned}
& \mathrm{T}_{1 / 2} \approx-\mathrm{In} 2 \times(\mathrm{K} 13+\mathrm{K} 31) / \\
& {\left[\mathrm{K} 31+\left(\mathrm{K} 12+\mathrm{K}_{\mathrm{T}}\right)\right]}
\end{aligned}
$$

\section{LONG TERM HCB CONCENTRATIONS IN THE BLOOD AND} ITS BIOLOGICAL HALF LIFE

Let us suppose that workers are exposed to a constant level of HCB. In these workers, blood concentrations of $\mathrm{HCB}$ reach an almost steady state after year term exposures. In this case, $\mathrm{dHCB} 1 / \mathrm{dt}$ and $\mathrm{dHCB} 3 / \mathrm{dt}$ can be considered as zero (as HCB1 and $\mathrm{HCB} 3$ have almost reached a steady state after year term exposure), and thus the blood concentrations will be approximated as:

$\mathrm{HCB} 1 \approx$ Dose $\times \mathrm{K}_{\mathrm{Ab}} /\left[\left(\mathrm{K} 12+\mathrm{K}_{\mathrm{T}}\right) \times \mathrm{VL}\right](\mathrm{B}-12)$

Therefore, Dose is given by:

$$
\begin{aligned}
& \text { Dose } \approx\left(\mathrm{K} 12+\mathrm{K}_{\mathrm{T}}\right) \times \mathrm{VL} \times \mathrm{HCB} 1 / \mathrm{K}_{\mathrm{Ab}} \\
& \approx(\mathrm{In} 2) \times\left[\left(\mathrm{K}_{13}+\mathrm{K} 31\right) / \mathrm{K} 31\right] \times \mathrm{VL} \\
& \quad \times \mathrm{HCB} 1 /\left(\mathrm{T}_{1 / 2} \times \mathrm{K}_{\mathrm{Ab}}\right)
\end{aligned}
$$

The calculated exposure dose levels that give a blood concentration of $200 \mathrm{ppb}$ (using Equation B-14 and applying the parameter values (table 4) are $18.2 \mathrm{mg}$ for the biological half life of 100 days, $5.02 \mathrm{mg}$ for 365 days, and $2.56 \mathrm{mg}$ for 730 days (table 5).

1 International Agency for Research on Cancer. Monographs on the evaluation of carcinogenic risk of chemicals to humans. Vol 20. Hexachlorobenzene. Lyon: IARC, 1979.

2 Currier MF, McClimans C, Barna-Lloyd G. Hexachlorobenzene blood levels and the health status of men employed in the manufacture of chlorinated solvents. J Toxicol Environ Health 1980;6:367-77.

3 Lunde G, Bjorseth A. Human blood samples as indicators of occupational exposure to persistent chlorinated hydrocarbons. Sci Total Environ 1977;8:241-6.

4 Yang RSH, Pittman KA, Rourke DR, Stein VB. Pharmacokinetics and metabolism of hexachlorobenzene in the rat and the Rhesus monkey. Journal of Agricultural and Food Chemistry 1978;26:1076-83.

5 Gad SC, Weil CS. Statistics for toxicologists. In: Hayes AW, ed. Principles and methods of toxicology. New York: Raven Press, 1982:273-320.

6 Koizumi A. Potential of physiologically based pharmacokinetics to amalgamate kinetic data of trichloroethylene and tetrachloroethylene obtained in rats and man. $\mathrm{Br} J$ Ind Med 1989;46:239-49.

7 Wester RC, Bucks DAW, Maibach HI, Anderson J. Polychlorinated biphenyls (PCBs): Dermal absorption, systemic elimination, and dermal wash efficiency. $J$ Toxicol Environ Health 1983;12:511-9.

8 Wester RC, Maibach HI. In vivo percutaneous absorption. In Marsulli FN, Maibach HI, eds. Dermatotoxicology. 2nd ed. Washington, DC: Hemisphere, 1982:131-46.

Accepted 14 January 1991 